\title{
Update on Onshore Disposal of Offshore Drilling Wastes
}

Prepared for:

U.S. Environmental Protection Agency Engineering and Analysis Division

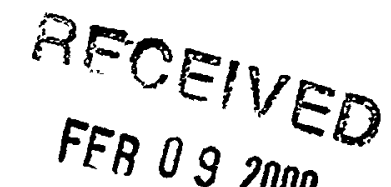

\author{
and
}

\author{
U.S. Department of Energy \\ Office of Fossil Energy \\ under Contract W-31-109-Eng-38
}

Prepared by:

John A. Veil

Argonne National Laboratory

Washington, D.C.

November 1999 


\section{DISCLAIMER}

- This report was prepared as an account of work sponsored by an agency of the United States Government. Neither the United States Government nor any agency thereof, nor any of their employees, make any warranty, express or implied, or assumes any legal liability or responsibility for the accuracy, completeness, or usefulness of any information; apparatus, product, or process. disclosed, or represents that its use would not infringe privately owned rights. Reference herein to any specific commercial product, process, or service by trade name, trademark, manufacturer, or otherwise does not necessarily constitute or imply its endorsement, recommendation, or favoring by the United States Government or any agency thereof. The views and opinions of authors expressed herein do not necessarily state or reflect those of the United States Government or any agency thereof. 


\section{DISCLAIMER}

Portions of this document may be illegible in electronic image products. Images are produced from the best available original document. 


\section{Introduction}

The U.S. Environmental Protection Agency (EPA) is developing effluent limitations guidelines to govern discharges of cuttings from wells drilled using synthetic-based muds. To support this rulemaking, Argonne National Laboratory was asked by EPA and the U.S. Department of Energy (DOE) to collect current information about those onshore commercial disposal facilities that are permitted to receive offshore drilling wastes. Argonne contacted state officials in Louisiana, Texas, California, and Alaska to obtain this information. The findings, collected during October and November 1999, are presented below by state.

\section{Louisiana}

Pierre Catrou of the Louisiana Department of Natural Resources, Office of Conservation (225342-5567; pierrec@dnr.state.la.us), has oversight responsibility for exploration and production (E\&P) waste management in Louisiana. He stated that, in his opinion, there is no shortage of disposal capacity for offshore wastes but did not provide details on the permitted commercial disposal facilities in Louisiana.

The majority of offshore E\&P wastes that come to shore in Louisiana for disposal are taken by work boat to one of the marine transfer facilities operated by Newpark Environmental Services. Newpark has transfer facilities in Venice, Bourg, Port Fourchon, Bateman Island, Morgan City, Intracoastal City, Mermentau, and Cameron. Wastes are loaded into barges and are hauled to Port Arthur, Texas where they are processed and loaded into tank trucks. The tank trucks haul the waste to an underground injection disposal site located in Fannett, Texas. Additional disposal capacity is available at the nearby Big Hill facility. EPA representatives and the author toured Newpark's Fannett and Port Arthur facilities on October 26, 1999. During that tour, Newpark officials reported that they have huge reserve disposal capacity, up to 1 billion barrels of waste at the Fannett site alone.

U.S. Liquids also operates a series of E\&P waste disposal facilities in Louisiana at Mermentau, Elm Grove, Bourg, and Bateman Island (Veil 1997, 1998). Treatment consists of land spreading and land treatment. U.S. Liquids used to own the marine transfer stations now operated by Newpark. Because it no longer operates marine transfer stations, U.S. Liquids receives almost none of the offshore wastes brought to shore. It only gets batches of waste that Newpark elects not to take, which does not happen often (Rick Sullivan - U.S. Liquids; 281-497-4606; November $3,1999)$. Nevertheless, this capacity remains available in the event that Newpark would be unable or unwilling to take offshore wastes. No information is available on the permitted disposal capacity of the U.S. Liquid facilities.

\section{Texas}

Oversight of commercial E\&P waste disposal facilities is handled by Richard Ginn (injection facilities; 512-463-6796; richard,ginn@rrastate.ts.us) and Jill Hybner (surface facilities; 512- 
463-6797; jill.hybner@mrs.state.tx.us) of the Railroad Commission of Texas. Both individuals provided information on those facilities that could potentially receive offshore drilling wastes. As noted above, the vast majority of offshore wastes are hauled by barge to Newpark's Port Arthur facility, where they are processed and trucked to the Fannett site for disposal by injection. Mr. Ginn reports that the Fannett site ( 6 injection wells) is permitted to dispose of 85,000 barrels of waste per day, and a similar site nearby, the Big Hill site ( 6 injection wells), is permitted to dispose of 57,000 barrels per day. Brandt Energy Environmental has a single injection well in the High Island field with a permitted capacity of 1,000 barrels per day, but the well is shut in due to operational problems, and permit cancellation is a possibility. The Railroad Commission is currently considering an application from Trinity Storage Services, L.P. for a salt cavern disposal facility in the Moss Bluff field. The proposed maximum disposal rate for the Trinity site would be 20,000 barrels per day.

Ms. Hybner provided a lengthy list of all commercial disposal facilities permitted by the Railroad Commission, a copy of which is attached as Appendix A. She marked those facilities that had some potential for receiving offshore wastes in italics type, although all but three of the facilities she marked are authorized to receive only water-based drilling fluids. The three facilities that are located reasonably close to the coast and are permitted to receive E\&P wastes other than waterbased drilling fluids are as follows:

1. Newpark Environmental Services - Port Arthur Treatment Facility (no capacity limit)

2. ECO Mud Disposal - Alice Facility (total capacity 2,049,882 barrels)

3. Waste Facilities, Inc. - Premont Facility (total capacity - 504,706 barrels)

\section{California}

Michael Stettner of the California Department of Conservation, Oil and Gas Division (916-3231781; stettner@consrv.ca.gov), provided partial information on facilities that can accept offshore waste for disposal. In an October 28 e-mail, Mr. Stettner provided information on three commercial disposal companies, as shown below:

1. company name:

address:

contact person:

phone number:

e-mail:

disposal method:

annual disposal capacity:

remaining disposal capacity:

2. company name:

address:

contact person:
Anadime Energy Services

$947 \frac{1}{2}$ East Main St.

Thomas Marquez

(805) 933-5925

AnadimeCA@aol.com

injection

24 truck loads/day

facility built in 1998/1999

GEO Petroleum, Inc.

18281 Lemon Drive, Yorba Linda, CA 92886

Dennis Timpe, President-Elect 
phone number:

disposal method:

annual disposal capacity:

remaining disposal capacity:
(714) 779-9897 Ext. 222

injection

unknown

unknown

Note: This facility has accepted offshore wastes in the past, but

is currently shut-in. The company is planning on returning the facility to operation.

3. company name:

address:

contact person:

phone number:

disposal method:

annual disposal capacity:

remaining disposal capacity:
Santa Clara Waste Water

815 Mission Rock Road, Santa Paula, CA

Bill Mundy

(805) 525-8315

sewer system

unknown

unknown

Mr. Stettner noted that he planned to forward information on additional disposal companies as soon as he hears back from other sources.

Veil (1997) identifies 13 California facilities that accept E\&P wastes. Many of these are located far from the ports where offshore vessels unload and, therefore, are not likely to receive offshore wastes. These are generally industrial waste treatment facilities or hazardous or nonhazardous landfills. Veil (1998) notes that one offshore California operator hauls oilbased muds and cuttings to shore in 6-cubic-yard boxes where the wastes are transferred to 15cubic-yard boxes for transportation to a landfill.

\section{Alaska}

Wendy Mahan of the Alaska Oil and Gas Conservation Commission (907-279-1433; wendy_mahan@admin.state.ak.us) provided information on drilling waste disposal practices in Cook Inlet and the North Slope. There are no commercial disposal facilities in Alaska for E\&P wastes, so operators have developed their own disposal systems. In the Cook Inlet area, several operators have historically used their own private landfills for E\&P waste disposal, but no such landfills are presently being used. All drilling wastes are now being disposed of through injection, either in dedicated injection wells or through annular injection in the well being drilled. Alaska allows up to 35,000 barrels of waste per well to be disposed of through annular injection. All facilities currently operating on the North Slope inject their drilling wastes. Ms. Mahan indicated that there should be no shortage of disposal capacity as long as operators are prepared to create new injection wells. 


\section{References}

Veil, J.A., 1997, "Costs for Off-site Disposal of Nonhazardous Oil Field Wastes: Salt Caverns versus Other Disposal Methods, " DOE/BC/W-31-109-Eng-38-2, prepared for U.S.

Department of Energy, National Petroleum Technology Office, by Argonne National Laboratory, September.

Veil, J.A., 1998, "Data Summary of Offshore Drilling Waste Disposal Practices," prepared for U.S. Environmental Protection Agency, Engineering and Analysis Division, and U.S. Department of Energy, Office of Fossil Energy, by Argonne National Laboratory, November. 


\section{Appendix A}

\section{RAILROAD COMMISSION OF TEXAS *COMMERCIAI SURFACE DISPOSAT, FACITITIES*}

(Permitted facilities are listed by group in the following order:

Pits, Stationary Treatment and Landfarm Facilities. Within each group, the permits are listed by district. This list does not include disposal/injection well facilities.)

\section{PITS}

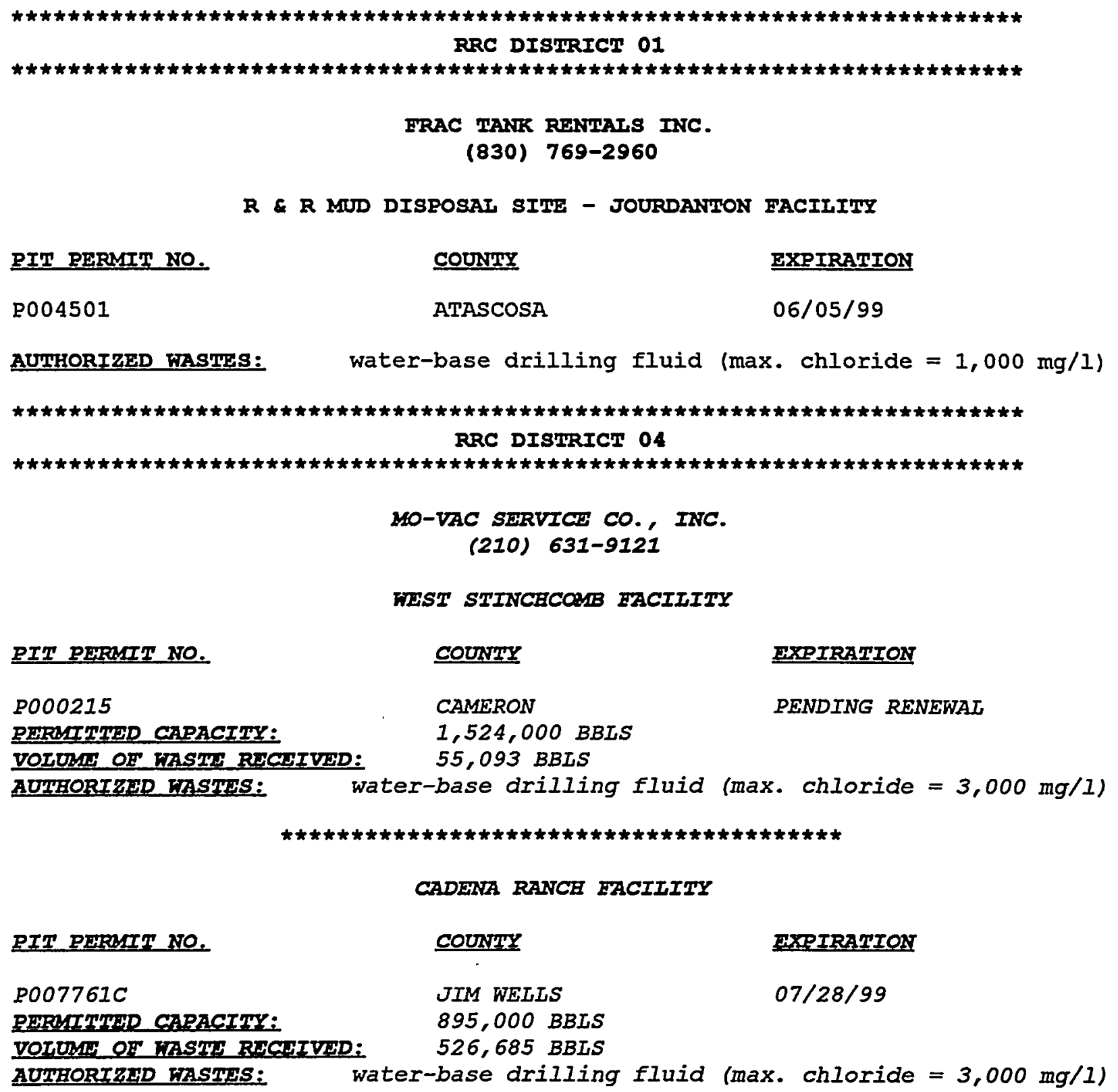


MO-VAC SERVICE CO., INC.

-CONTINUED-

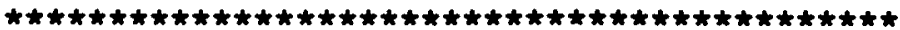

GARAATAY BACILITYY

PIT PREMTT NO.

P009769

PRHMITYYHD CAPACTTY:

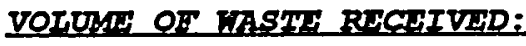

P009770

PBFMTTTHD CARACTITY:

VOTOMA OF HASTW RSCAIVAD:

FXPIRATION

$04 / 19 / 00$

HIDALGO 165,000 BBLS

64,815 BBLS

HIDALGO

695,000 BBLS

417,114 BBLS

$04 / 19 / 00$

AUTHORIZEP FASTE: Oil-free water base drilling fluid \& waste from washout of vacuum trucks (max. chlorides $=3,000 \mathrm{mg} / \mathrm{l}$ )

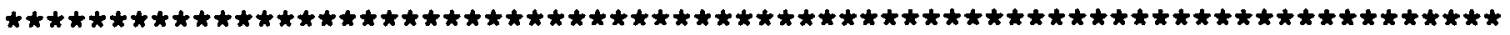

SMITH, KRARON

(956) $381-0230$

MMITH DISPOSAI FACILITY

PIT PEFMIT No.

P009559

AUTHORIZED FASTE:

\section{COUNTY}

HIDALGO oil free, water-base drilling fluid (max. chlorides = $3,200 \mathrm{mg} / 1$ )

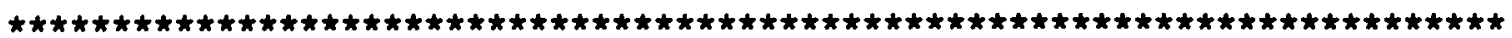

WASTE FACILITIES, INC.

(512) $348-3966$

NANO RANCH FACIIITY

PIT PRRMIT NNO.

COUNTII

EXPIRATION

P010655

AUTHORIZED WASTE:

ZAPATA

PENDING RENEWAI

water base drilling fluid and associated cuttings and waste fluids from washout pits (max. chlorides $=6,000$ $\mathrm{mg} / 1$ )

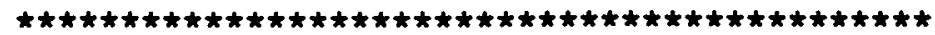

RANCHO NUEVO DISPOSAI FACIIITY

PIT PERMIT NO. P010887

AUTHORIZED FASTH:

COUNTIY EXPIRATION

DUVAI

06/03/02

water base drilling fluid and associated cuttings (max. chlorides $=3,000 \mathrm{mg} / \mathrm{I}$ )
\end{abstract}




\begin{tabular}{|c|c|}
\hline \multicolumn{2}{|c|}{ 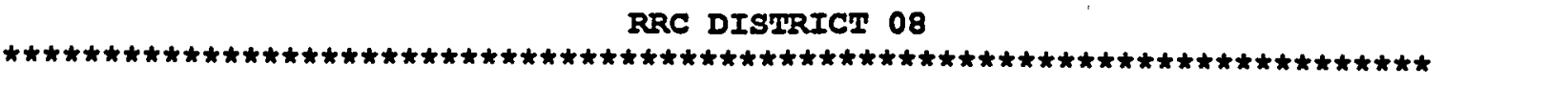 } \\
\hline \multirow{2}{*}{\multicolumn{2}{|c|}{$\begin{array}{l}\text { FESTEX NOTREES, I.C. } \\
\text { (915) 570-4229 }\end{array}$}} \\
\hline & \\
\hline PIT PERMIT NO. & EXPIRATION \\
\hline $\begin{array}{l}\text { P010501 } \\
\text { P010619 } \\
\text { P010646 } \\
\text { P010647 } \\
\text { P010669 } \\
\text { P010670 } \\
\text { P010672 } \\
\text { P010673 }\end{array}$ & $\begin{array}{l}\text { PENDING RENEWAL } \\
\text { PENDING RENEWAI } \\
\text { PENDING RENEWAI } \\
\text { PENDING RENEWAI } \\
\text { PENDING RENEWAI } \\
\text { PENDING RENEWAI } \\
\text { PENDING RENEWAI } \\
\text { PENDING RENEWAI }\end{array}$ \\
\hline AUTHORIZHD WASTE: & $\begin{array}{l}\text { non-injectable wastes which fall within the oil \& gas } \\
\text { exemption of RCRA and do not exceed } 7 \% \text { in oil content as } \\
\text { determined by a standard API shakeout; non-reclaimable, } \\
\text { RCRA exempt oil base drilling mud; contaminated soils } \\
\text { from lube oil spills; contaminated soils from RCRA non- } \\
\text { exempt crude oil spills and absorbent pads from these } \\
\text { spills; compressor filters (no wastes such as metal or } \\
\text { oil may be disposed of in pits if that material is } \\
\text { recyclable or reclaimable); and wastewater from the } \\
\text { washout of tanks used to haul exempt waste to this site. }\end{array}$ \\
\hline
\end{tabular}

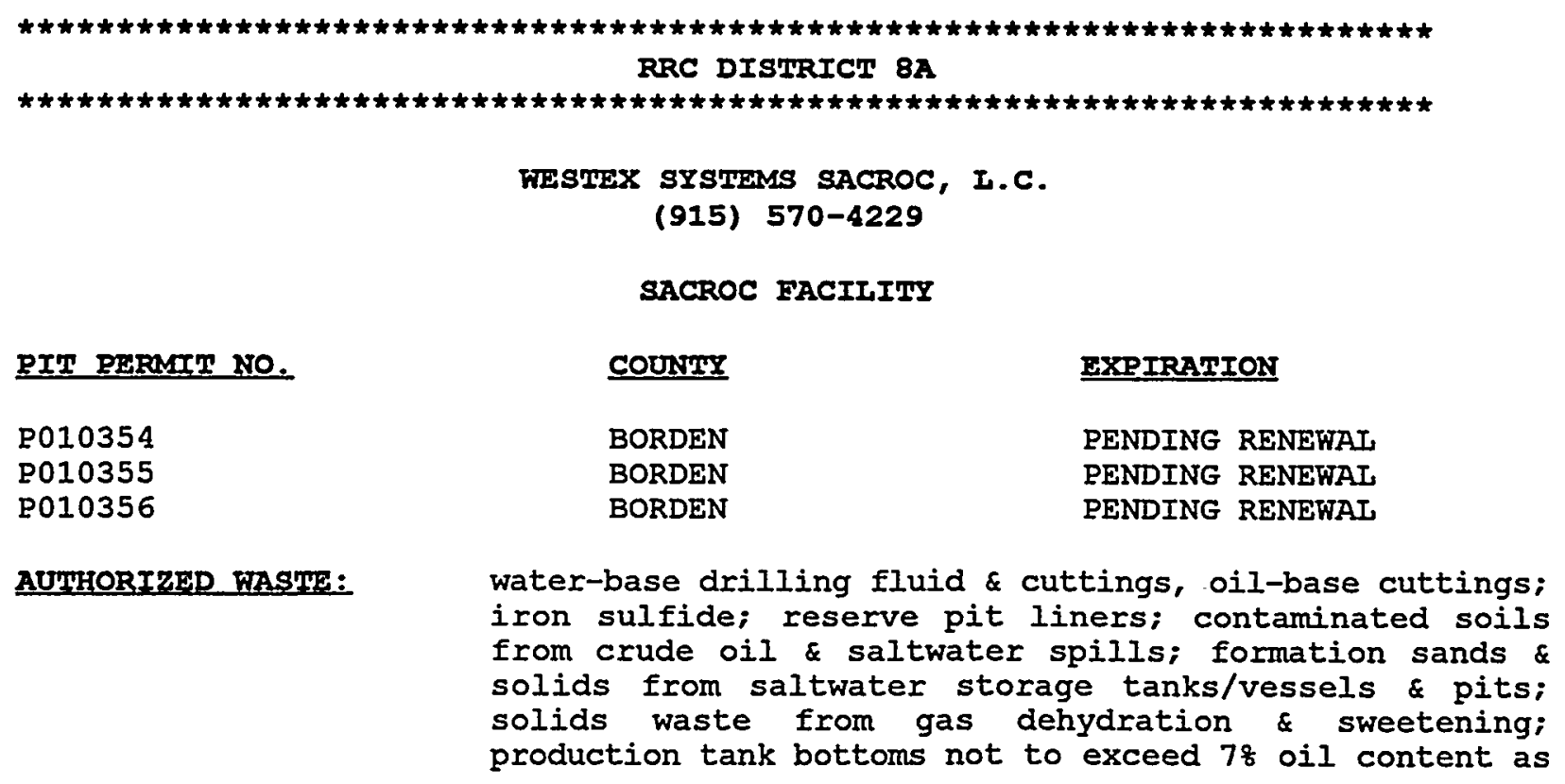



determined by standard API shakeout; crude oil
reclamation waste

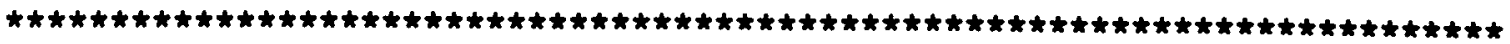

FILIIAMS OII FIELD DISPOSAT SFSTHM

(915) 573-4051

HIIIIAMS PROPERTY EACIIITY

PIT PERMIT NO.

COUNTIY

BORDEN RENDING TRANSEER

BORDEN $\quad$ PENDING TRANSFER

BORDEN $\quad$ PENDING TRANSFER

BORDEN PENDING TRANSFER

BORDEN PEND. RENEWAL/TRANSEER

P002490

AUTHORIZED FASTE:

PIT PERMIT NO.

P006192

AUTHORIZED WASTE:

PIT PERMIT NO.

P010469

AUTHORIZED MASTE:

non-hazardous oil \& gas waste

COUNTIY

EXPIRATION

BORDEN PEND. RENEWAL/TRANSEER

drilling fluid (max. chlorides $=50,000 \mathrm{mg} / \mathrm{l}$ )

COUNTYY

FXPIRATION

BORDEN

PEND. RENEWAL/TRANSEER

non-hazardous RRC regulated waste which pass the paint Filter Test (EPA Method 9095) and have a TPH of $<2 \%$

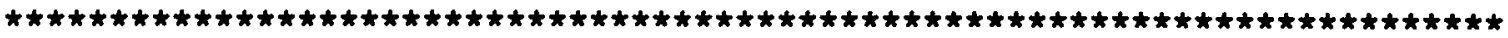

RRC DISTRICT 09

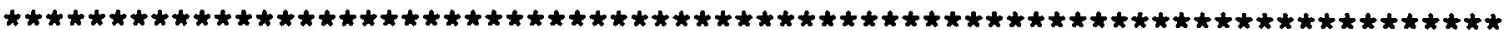

NONNETEY, BART

(817) $825-3222$

NUNNEIEY RANCH EACILITY

PIT PEFEMTT NOS.

$\mathrm{P} 007726$

AUTHORIZED FASTE:

COUNTY

MONTAGUE

\section{EXPIRATION}

$02 / 09 / 00$

water base drilling fluid and associated cuttings (max. chlorides $=3,000 \mathrm{mg} / \mathrm{l}$ )
} 


\section{STATIONARY TREATMENT FACILITIES}

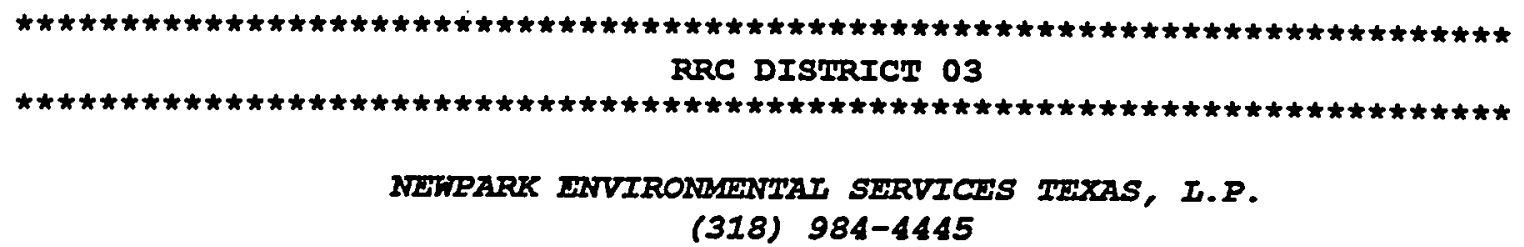

PORT ARTHUR TRFATMAHN EACIIITY

STE PDERIT NO.

COUNTY

STE-001

PIHPLITIFD CAPACTEX:

VOLUAN OE HASTY RECWIVED:

AUTHORTZED MASTH:

PIT PHFMTI NOO.

P009890

P009891

AUTHORIZED WASTE:

PIT PERMIT NO.

P010789

P010792

AUTHORIZED FASTE:

PIT PERMIT NO.

P010108

AUTHORIZED TASTE:

COUNTYY

COUNTY

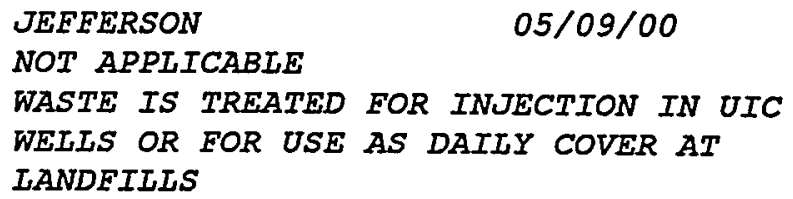

JEFEERSON NOT APPLICABLE

WASTE IS TREATED FOR INJECTION IN UIC WELIS OR FOR USE AS DAILY COVER AT IANDEILIS

authorized to receive and treat non-hazardous oil and gas wastes, including oil and gas waste from Mexico

$$
\text { - PITs - }
$$

BXPIRATION

$\begin{array}{ll}\text { JEFEERSON } & 05 / 09 / 00 \\ \text { JEFEERSON } & 05 / 09 / 00\end{array}$

temporary storage of processed solids generated onsite from the treatment of non-hazardous oilfield waste

COUNTIY

$\begin{array}{ll}\text { JEEEERSON } & 05 / 09 / 00 \\ \text { JEEEERSON } & 05 / 09 / 00\end{array}$

collection of waste authorized by STF-001 and washwater from washout of containers used to transport waste material to facility

EXPIRATION

SAN PATRICIO

$02 / 23 / 00$

non-pumpable waste authorized by STF-001 (located at Ingleside Transfer station) 
TRANSCON EMTHEY CORPORATION

(956) 765-5981

GOIDEN TIRIANGIE INDUSTRIES PROP.
STE PFFMTT NO.

STE-010

AUTHQRIZED FASTY:
COUNWY

COLORADO

\section{EXPIRATION}

$03 / 10 / 00$

water base drilling fluid and the associated cuttings; oil base drilling fluids and the associated cuttings; tank bottoms from gas plants, crude oil reclamation plants, and crude oil production/separation facilities; waste material from produced water collecting pits; produced formation sand; and soil contaminated with produced water, crude oil, or condensate; non-liquid wastes from gas dehydration and sweetening; spent activated carbon and other filtering and separation media.

*Not yot' authorized to except waste*

RRC DISIRICT 04

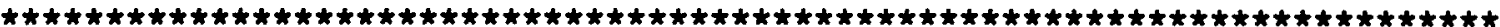

US IIQUIDS OF IAA, IP

(713) 512-6262

SOUTH TEXAS DISPOSAI EACIIITY

STE PERMIT NO.

STE-006 (*)

AUTHORIZED FASTE:
COUNTIY

ZAPATA

\section{EXPIRATION}

$08 / 30 / 00$

non-injectable, water base drilling fluid and the associated cuttings; non-reclaimable, non-haz. tank bottoms from gas plants, crude oil reclamation plants and crude production/separation facilities, noninjectable, non-haz. waste material from produced water collecting pits; produced formation sand; soil contaminated with produced water or crude oil; solid wastes from gas dehydration and sweetening, such as spent glycol and amine filters, solid filter media, molecular sieves, and precipitated amine sludge, iron sponge, and hydrogen sulfide scrubber; iron sulfide; spent activated carbon and other filtering and separation media; liners from pits that contained exempt oil \& gas wastes; inert wastes as defined by statewide Rule 8 such as uncontaminated concrete or wood; and 
other non-haz, oil \& gas wastes generated in connection with the exploration, development and production of oil \& gas resources

\author{
US IIQUIDS OF IA, IP \\ -continued-
}
(*) includes treatment basins (Pit Permit Nos. P010236, P010237, P010238, P010239, P010240, and P010241), landtreatment cells and landfill

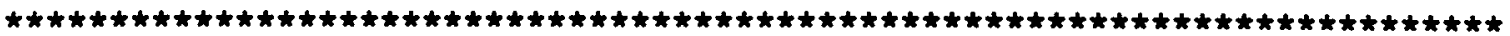

JCO MUD DISPOSAL

(512) $887-2183$

ALICE FACILITY

STE PERMET NOO.

COUNTIY

TXPIRATION

$S T F-003$

JIM WELLS

$01 / 16 / 03$

PEFMITTKDD CAPACITY:

$2,049,882$ BBLS

VOLUME OF FASTE RECEIVED: 961,883 BBLS

AUTHORIRHR ITSTY: non-reclaimable oil base drilling fluid, cuttings generated while using oil base drilling fluid, and nonhaz., oily waste containing no reclaimable oil

-PITS-

GARCIA LEASE (TANK NOS. $1,2,3$ )

PIT EEPAIT NO.

P001212

$\mathrm{P} 001213$

P010913

AUTHORIZED WASTE:

PIT PERMIT NO.

P001215

AUTHORIZFP WASTP:

COUNTYY

JIM WELLS
JIM WELLS
JIM WELLS

non-reclaimable oil base drilling fluid, cuttings generated while using oil base drilling fluid, and nonhaz., oily waste containing no reclaimable oil

GARCIA IEASE (CALICHE RIT)

COUNTYY

EXPIRATION

$01 / 16 / 03$

$01 / 16 / 03$

$01 / 16 / 03$

\section{JIM WELLS}

\section{EXPIRATION}

$01 / 16 / 03$

waste specified in STF-003 consisting of non-reclaimable oil base drilling fluid, cuttings generated while using oil base drilling fluid, and non-haz., oily waste containing no reclaimable oil
\end{abstract}


TEXAS OILFIELD ENVIRONMENTAL SERVICES, INC.

(512) $884-2400$

DON CAMERON RANCE

STE PGPMIT NO.

STE-009

AUTHORIZFP WASTH:
COUNTYY

STARR
EXPIRATION

$04 / 09 / 02$

water base drilling fluid and the associated cuttings; oil base drilling fluids and the associated cuttings; tank bottoms from gas plants, crude oil reclamation plants, and crude oil production/separation facilities; waste material from produced water collecting pits; produced formation sand; and soil contaminated with produced water, crude oil, or condensate; includes pit 010964, this is a washout pit. 


\title{
I.ANDFARMING FACIIITIES
}

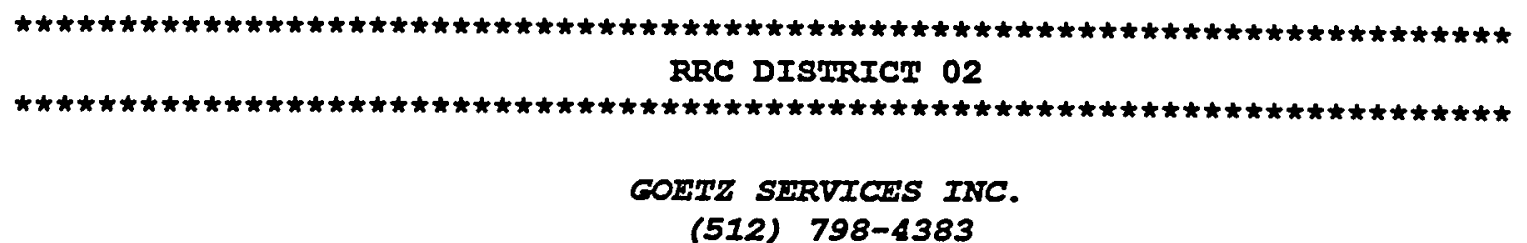

T. W. ILEY, JR. RROPERTY

\begin{abstract}
PEFAIT NO. SOUNTY
$L F-0213$

PIRPTTEPD CAPACITY:

LIVE OAK

258,824 BBLS

VOLUMA OF WASTE RECEIVED: $\quad 16,610$ BBLS

AUTHORIZHD WASTE: water base drilling fluid (max. chlorides $=3,000 \mathrm{mg} / \mathrm{l}$ )

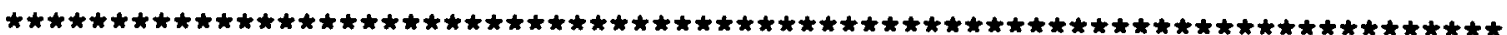

R \& R REMEDIATION SERVICES, INC.

(210) 697-0686

BEXAR COUNTY FACIIITY

PERMIT NO.

LT 0150

AUTHORIZED FASTE:

COUNTY

BEXAR

\section{EXPIRATION}

PENDING RENEWAL

water base drilling muds and associated cuttings; nonreclaimable oil base drilling muds and the associated cuttings; waste material from produced water collecting pits; produced formation sand; and soil contaminated with produced water or crude oil
\end{abstract}




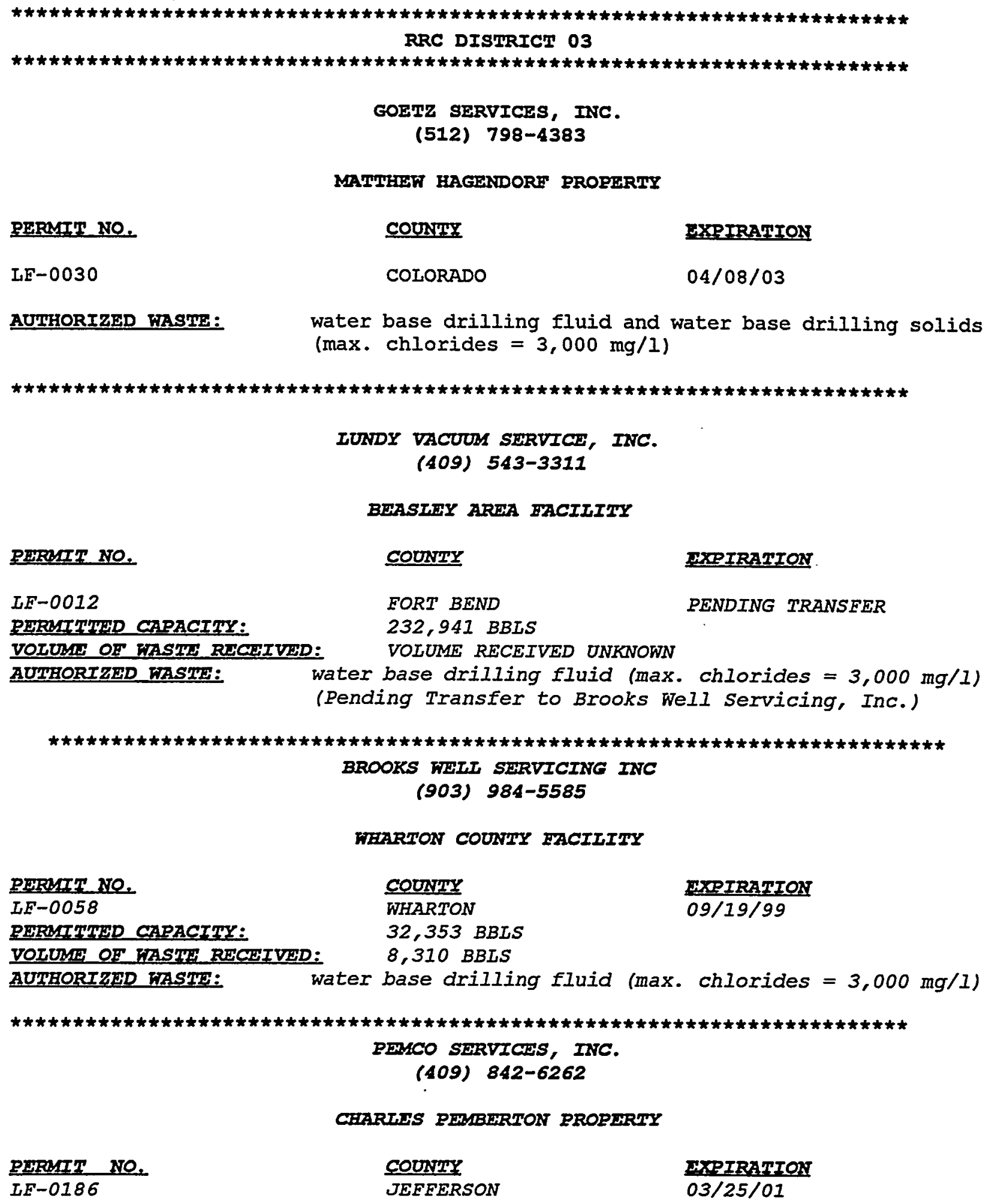


TOS GIII SHRVICES ITC

(512) $882-3153$

TOM GIII BACIIITY

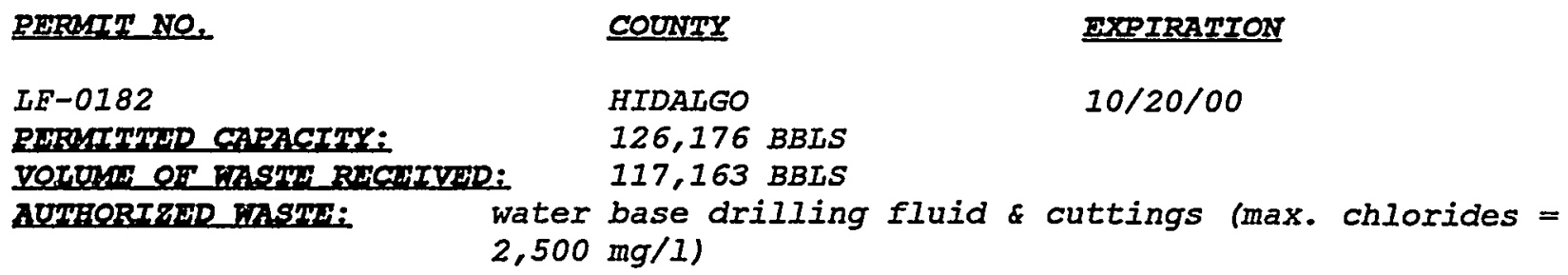

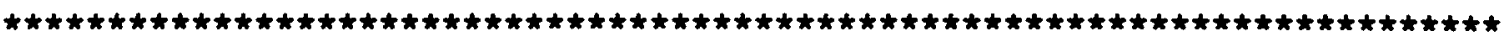

HASTE EACILITIES, INC.

(512) $348-2890$

PRWMONT EACIIITY

PFERIT NO, COUNTY FXPIRATION

$L T-0078$

PHFYITHFD CAPACTTY: .

JIM WELLS

504,706 BBLS

VOTUMN OF TASTH RHCHIVHD: 362,294 BBLS AUTHORTZED TASTH:

only non-haz. materials allowed; non-injectable water base drilling fluid and cuttings; non-reclaimable oil base drilling fluids and cuttings; non-reclaimable tank bottoms from crude oil reclamation plants and crude oil production/separation facilities; non-injectable waste material from produced water collecting pits; produced formation sand; soil contaminated with produced water or crude oil. Treated waste is authorized for disposal in the pit covered under Pit Permit No. P010957.

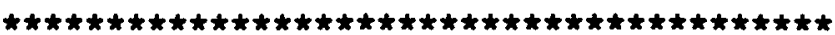

FFI BUSTAMANTE EACIIITY

PERMII NO.

$\mathrm{IT}-0218$

AUTHORTZED FASTH:
COUNTYY

ZAPATA

\section{EXPIRATION}

$04 / 23 / 04$

only non-haz, materials allowed; non-injectable water base drilling fluids and associated cuttings; nonreclaimable tank bottoms from crude oil reclamation plants and crude oil production/separation facilities; non-injectable waste material from produced water 
collecting pits; produced formation sand, soil contaminated with produced water, crude oil or hydrocarbon condensate.

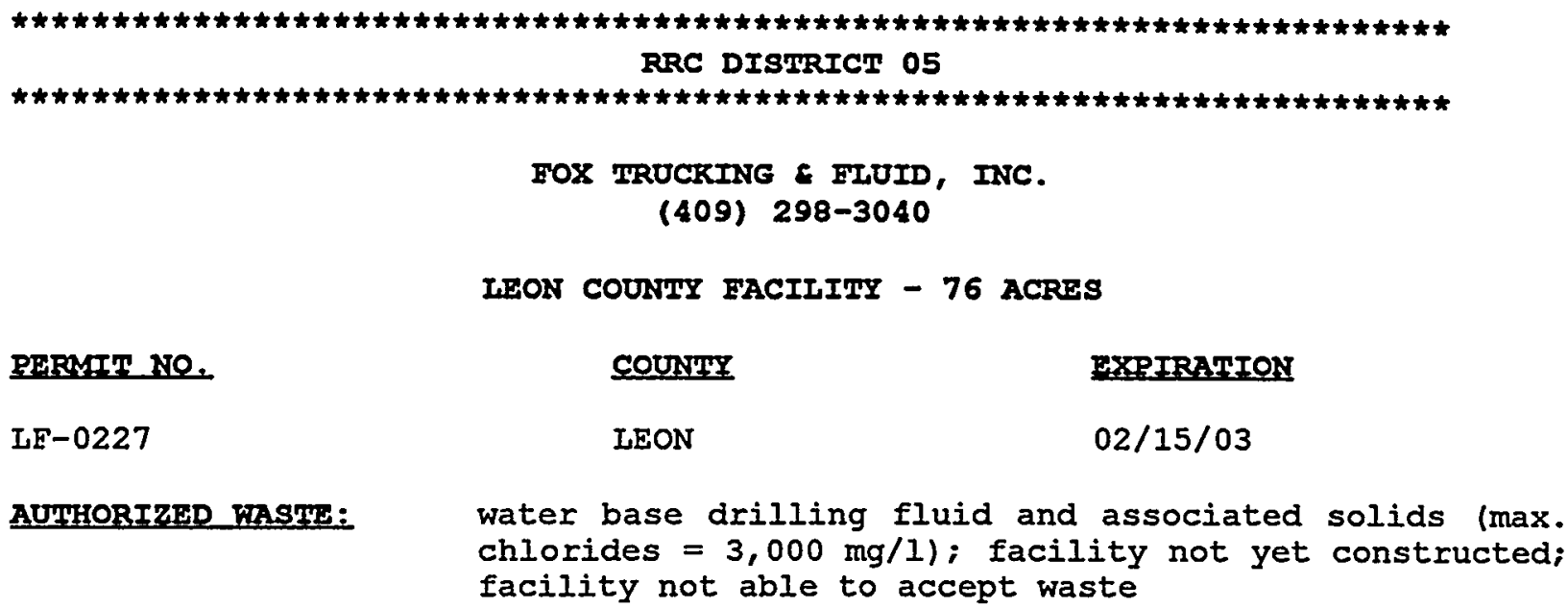

PFPMIT NO,

LF-0227

AUTHORIZED WASTE:

\section{COUNHFI}

LEON

water base drilling fluid and associated solids (max. chlorides $=3,000 \mathrm{mg} / 1$ ); facility not yet constructed; facility not able to accept waste

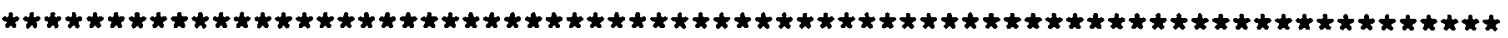
RRC DISTRICT 08 .

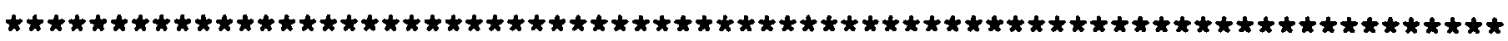

BASIC REMEDIATION, INC.

(915) 683-0913

BOOT HILI EACIIITY (NOT YET CONSTRUCTED)

PERMIT NO,

\section{COUNPY}

\section{EXPIRATION}

LT-0152

AUTHORIZED WASTE:
ECTOR
$09 / 10 / 01$ only non-haz. crude oil contaminated soil from spills subject to the jurisdiction of the jurisdiction of the Railroad Commission of Texas may be received, stored, handled, treated or disposed of at the facility.

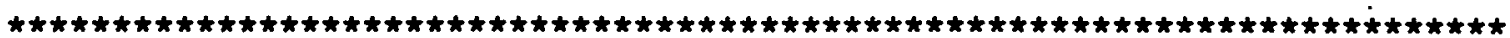

RCM OII, INC.

(800) $654-7150$

\section{RICKY SMITH RANCH FACIIITY}

PEPMTT NO.

LT -0136

AUTHORTZED FASTE:

\section{COUNIYY}

WINKLER

only non-haz, crude oil contaminated soil from spills subject to the jurisdiction of the RRC; no waste may be 
disposed of at the facility if that material is reclaimable.

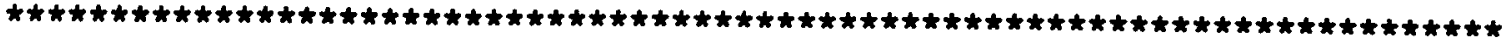

SOUHHFEST DISPOSAI SERVICE, INC.

(602) 996-2449

PENFELI FACILITY (NOT YET CONSTRUCTTD)

PERMIT NO.

LE-0045

AUTHORIZED WASTE:

COUNTII

ECTOR

EXPIRATION

PENDING RENEWAL

only non-haz. materials allowed; water base drilling fluid \& cuttings; non-reclaimable oil base drilling fluid and cuttings; waste water from dikes, sumps, pits \& crude oil reclamation plants; non-reclaimable tank bottoms from gas plants, crude oil reclamation plants and production facilities; waste material from collecting pits; produced formation sand; oily washwater; top soil contaminated with produced water \& other oily waste generated in connection with activities associated with exploration, development \& production of oil \& gas resources.
\end{abstract}

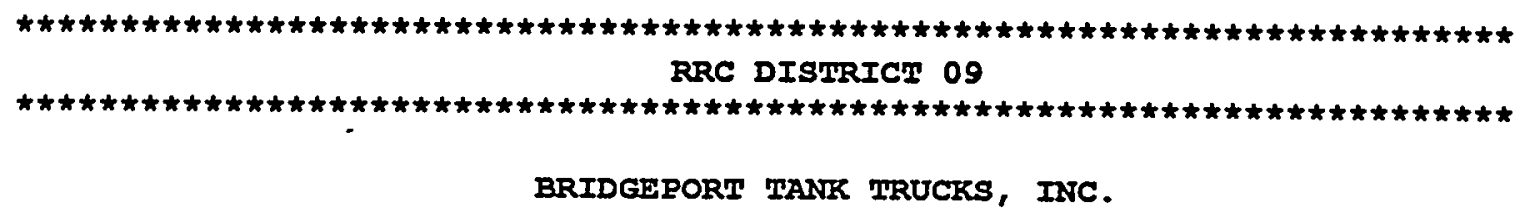

HOLLEY MOD DISPOSAI FACILITY

\section{PERMIT NO,}

LE-0229

AUTHORIZED FASTH:

\section{COUNTY}

WISE

$11 / 17 / 03$

water base drilling fluid and associated solids (max. chlorides $=3,000 \mathrm{mg} / \mathrm{l})$; associated pit permits are P010994 and P010995, these are drilling fluid storage pits; facility not yet able to accept waste

QUALITY OILFIELD SERVICE, INC.

(940) $644-2216$

QOS FACILITY 
PREMIT NQ.

LF-0238

RUTRHORTERD MASTR:
COUNITY

MONTAGUE

\section{EXPIRATION}

$09 / 30 / 03$

water base drilling fluid and associated solids (max. chlorides $=3,000 \mathrm{mg} / \mathrm{I})$; associated pit permit is P011020, this is a drilling fluid storage pit; facility not yet constructed 